JURNAL KETAHANAN NASIONAL

P-ISSN: 0853-9340, e-ISSN: 2527-9688

Online sejak 28 Desember 2015 di: http://jurnal.ugm.ac.id/JKN

\title{
OPTIMALISASI PERAN KODIM \\ DALAM PENANGANAN TANGGAP DARURAT BENCANA ALAM DAN IMPLIKASINYA TERHADAP KETAHANAN WILAYAH (Studi Di KODIM 0613/Ciamis, Jawa Barat)
}

\author{
Ito Hediarto \\ Pusdikzi Kodiklat TNI AD \\ E-mail : ito.hediarto@yahoo.com \\ Armaidy Armawi \\ Fakultas Filsafat Universitas Gadjah Mada \\ armaidy@ugm.ac.id \\ Edhi Martono \\ Fakultas Pertanian Universitas Gadjah Mada \\ edhi.martono@ugm.ac.id
}

\begin{abstract}
The goal of this research was to understood the Optimization of the Role of the 0613 Military District Command (Kodim) Ciamis in Rapid Response of Natural Disasters and Its Implication to Regional Resilience.

This research was a descriptive qualitative one. Data collection was conducted by in-depth interview technique to 10 personnel including the Commander, Staff and members of Kodim 0613/Ciamis, along with observation and reference studies to gathered data and then they were qualitatively analyzed. The result of the research provided the answer that Kodim 0613/Ciamis can offer its role in rapid response of natural disasters in Ciamis Regency, West Java. The activities conducted through rapid assessment and determining the status of damaged region and resources, rescue and evacuation of vulnerable groups, providing the basic needs and emergency recovery.

A rapid assessment was conducted when a disaster information was received in Ciamis area, by quickly processing the information, rescue or evacuation conducted by Kodim 0613/Ciamis after the disaster occurred and in cooperation with BPBD Ciamis Regency, the provision of basic needs was conducted by Kodim 0613/Ciamis in order to carried out emergency response program, condition recovery conducted by cooperation between TNI, Polri, and local community and government. The success of Kodim 0613/Ciamis in emergency response resulted in positive impact to the social condition in Ciamis Regency, and bolster the resilience of Ciamis Regency that includes resilience in ideology, politics, economy, socio-culture and defense and security.

To optimized the role of Kodim 0613/Ciamis in emergency response, therefore a mechanism should be formulated where Commander of Kodim (Dandim) was entrusted with greater role in decision making during emergency. The Regent (Bupati) may appoint Dandim as the Incident Commander (IC), so that Dandim was able to take swift actions in rescuing and evacuating the victims and restoring the damaged region. Kodim 0613/Ciamis could be regarded as the model of emergency response for other regions.
\end{abstract}

Keywords : Role of Kodim, Emergency Response, Regional Resilience 


\begin{abstract}
ABSTRAK
Penelitian ini bertujuan untuk mengetahui Optimalisasi Peran Komando Distrik Militer 0613/Ciamis Dalam Penanganan Tanggap Darurat Bencana Alam Dan Implikasinya Terhadap Ketahanan Wilayah.

Penelitian ini merupakan deskriptif kualitatif. Pengumpulan data dilakukan dengan teknik wawancara mendalam, yang dilakukan terhadap 10 orang, yaitu Komandan, Staf dan anggota Kodim 0613/Ciamis, selain itu juga melalui observasi serta studi pustaka untuk diperoleh data lalu dianalisis secara kualitatif. Hasil penelitian ini memberikan jawaban bahwa Kodim 0613/Ciamis dapat berperan maksimal dalam menangani tanggap darurat bencana alam di Kabupaten Ciamis Jawa Barat. Kegiatan dilakukan melalui pengkajian secara cepat dan penentuan status terhadap lokasi kerusakan dan sumber daya, penyelamatan atau evakuasi dan perlindungan kelompok rentan, pemenuhan kebutuhan dasar, serta pemulihan kondisi darurat.

Kegiatan pengkajian cepat dilakukan bila ada informasi bencana di wilayah Ciamis, dengan segera informasi tersebut diolah, penyelamatan atau evakuasi dilakukan oleh Kodim 0613/Ciamis setelah terjadi bencana dan bekerjasama dengan BPBD Kabupaten Ciamis, pemenuhan kebutuhan dasar dilakukan oleh Kodim 0613/Ciamis dalam rangka melaksanakan program tanggap darurat bencana, pemulihan kondisi darurat dilakukan kerjasama antara aparat TNI, Polri, dan masyarakat serta pemerintah daerah. Keberhasilan Kodim 0613/Ciamis dalam menangani tanggap darurat memberikan dampak yang positif terhadap situasi kondisi sosial di Kabupaten Ciamis, dan berimplikasi terhadap ketahanan wilayah Kabupaten Ciamis yang meliputi ketahanan idiologi, ketahanan politik, ketahanan ekonomi, ketahanan sosial budaya dan ketahanan pertahanan keamanan.

Untuk lebih mengoptimalkan peran dari Kodim 0613/Ciamis dalam menangani tanggap darurat, maka perlu diciptakan mekanisme yaitu Dandim diberikan peran yang lebih besar dalam mengambil tindakan saat tanggap darurat. Bupati dapat menunjuk Komandan Kodim sebagai komandan posko tanggap darurat Incident Commander (IC), sehingga Dandim dapat mengambil tindakan cepat dalam menolong dan mengevakuasi korban serta mengembalikan kondisi lingkungan yang rusak akibat bencana. Kodim 0613/Ciamis dapat dijadikan sebagai model dalam penanganan bencana bagi wilayah lainnya.
\end{abstract}

\title{
Kata Kunci : Peran Kodim, Tanggap Darurat, Ketahanan Wilayah
}

\section{PENGANTAR}

Bencana adalah suatu gangguan serius terhadap masyarakat yang menimbulkan kerugian secara meluas dan dirasakan, baik oleh masyarakat berbagai material dan lingkungan (alam), dimana dampak yang ditimbulkan melebihi kemampuan manusia guna mengatasinya dengan sumber daya yang ada. Bencana ialah sebuah kejadian yang tidak biasa terjadi disebabkan oleh alam maupun ulah manusia, termasuk pula di dalamnya merupakan imbas dari kesalahan teknologi yang memicu respons dari masyarakat, komunitas, individu maupun lingkungan untuk memberikan antusiasme yang bersifat luas. Daerah rawan bencana dengan jumlah penduduk yang besar, jika diimbangi dengan ketahanan terhadap bencana yang cukup, maka wilayah tersebut dapat mengeliminir dampak bencana.

Berbagai bencana alam telah terjadi di Indonesia dengan segala upaya penanggulangannya. Indonesia merupakan negara yang sangat rawan dengan bencana alam seperti gempa bumi, tsunami, letusan gunung berapi, tanah longsor, banjir dan angin puting beliung. Sekitar 13 persen gunung berapi dunia yang berada di kepulauan Indonesia berpotensi menimbulkan bencana alam dengan intensitas dan kekuatan yang berbeda-beda. Laporan Penilaian Global Tahun 2009 pada Reduksi Resiko Bencana juga memberikan peringkat yang tinggi untuk Indonesia pada level pengaruh bencana terhadap manusia, yaitu peringkat 3 dari 153 untuk gempa bumi dan 1 dari 265 untuk tsunami (Kuntjoro dan Jamil, 2010). 
Ito Hediarto, Armaidy Armawi, Edhi Martono -- Optimalisasi Peran Kodim Dalam Penanganan Tanggap Darurat Bencana Alam Dan Implikasinya Terhadap Ketahanan Wilayah (Studi Di Kodim 0613/Ciamis, Jawa Barat)

Badan Penanggulangan Bencana Daerah (BPBD) direncanakan di semua provinsi namun baru didirikan di 18 daerah, selain itu, kelemahan manajemen bencana di Indonesia salah satunya dikarenakan kurangnya sumber daya dan kecakapan Pemerintah Daerah yang masih bergantung kepada Pemerintah Pusat. (Kuntjoro dan Jamil, 2010).

Setelah peristiwa bencana alam tsunami Aceh yang membuat Indonesia berduka, juga telah terjadi tsunami Pangandaran yang terletak di Kabupaten Ciamis Jawa Barat pada tanggal 16 Juli 2006, yang membuat seluruh masyarakat Indonesia terperangah kepada kekuatan alam. Sebuah gempa yang diawali dengan datangnya gelombang besar di pantai Pangandaran Jawa Barat itu berkekuatan 6,8 pada skala richter. Kejadian bencana alam lainnya yang sering terjadi di Kabupaten Ciamis Jawa Barat adalah berupa tanah longsor, banjir ataupun angin puting beliung. Seringnya longsor dan banjir menurut BPBD Ciamis Jawa Barat dikarenakan struktur tanah di wilayah Ciamis yang relatif labil dan dikombinasikan dengan dampak gundulnya pepohonan di beberapa gunung yang ada, seperti halnya yang terjadi bencana alam di Kecamatan Cihaurbeuti Kabupaten Ciamis pada tanggal 28 Maret 2011, yang mengakibatkan dua orang meninggal dunia dan sekitar tujuh ratus orang masyarakat mengungsi dari lokasi bencana.

Kejadian-kejadian bencana yang terjadi di Kabupaten Ciamis Jawa Barat ternyata tidak diantisipasi secara konkrit di lapangan. BPBD Ciamis seolah tidak berdaya menghadapi gempuran bencana yang datang silih berganti di beberapa kecamatan. Pada kondisi ini peran Komando Kewilayahan seperti Kodim 0613/Ciamis sangat dibutuhkan, fakta yang ada menunjukan bahwa dengan penggelaran seluruh Koramil dan Babinsa hingga di pelosok desa bisa menjadi mata dan telinga para pengambil keputusan di daerah, termasuk bila terjadi bencana alam, lebih khusus lagi pada tahap tanggap darurat.

Sementara kondisi yang terjadi di wilayah Ciamis Jawa Barat belum mandiri, BPBD Kabupaten Ciamis yang masih merupakan lembaga baru yang terbentuk tahun 2010, ternyata belum bisa banyak berbuat ketika menghadapi bencana alam, seperti banjir bandang di Kecamatan Cihaurbeuti yang terjadi tahun 2011. Hal tersebut terjadi mengingat minimnya pengalaman dan sulitnya dalam pelaksanaan manajemen bencana. Ternyata yang banyak mengambil alih komando dan pengendalian saat itu adalah Kodim 0613/Ciamis yang merupakan Komando Kewilayahan dengan gelar pasukan yang ada hingga tiap Kecamatan. Pada saat awal terjadi bencana, prajurit TNI yang berada di Kecamatan Cihaurbeuti dengan kekuatan yang tidak banyak justru sangat banyak membantu langkah awal dalam penanggulangan bencana, hingga keluarnya pernyataan kondisi tanggap darurat dari Bupati Ciamis. Selain itu Kodim 0613/Ciamis ikut berperan dalam rehabilitasi pasca bencana.

Demikian juga dengan bencana tsunami yang terjadi di wilayah Pangandaran pada tahun 2006, ternyata menempatkan Kodim 0613/Ciamis sebagai penggerak utama dalam penanggulangan bencana. Selain itu hampir semua bantuan yang datang dari lembaga-lembaga sosial diterima oleh Kodim 0613/Ciamis dan disalurkan kepada warga masyarakat yang terkena dampak bencana tsunami di Pangandaran. Memang pada saat itu belum ada lembaga BPBD, akan tetapi 
dapat terlihat dengan jelas, bagaimana peran dari Kodim 0613/Ciamis dengan sangat cepat dapat menjadi pionir dalam tanggap darurat bencana, kenyataannya pemerintah daerah Kabupaten Ciamis dapat mengerti tentang hal tersebut.

Hal inilah yang menjadi pendorong bagi peneliti untuk melihat lebih jauh dan dengan jelas bagaimana peran dari Kodim 0613/Ciamis dalam penanganan tanggap darurat bencana, sehingga dapat dijadikan sebagai konsep atau role model bagi daerah lain ke depan guna penanganan tanggap darurat bencana alam. Oleh sebab itu pokok permasalahan yang diangkat dalam penelitian ini yaitu (1). Bagaimana peran Kodim 0613/ Ciamis dalam menangani tanggap darurat bencana alam di Kabupaten Ciamis Jawa Barat ?, (2). Kendala apa yang dihadapi Kodim 0613/Ciamis dalam menangani tanggap darurat bencana alam di Kabupaten Ciamis Jawa Barat ?, dan (3). Bagaimana strategi optimalisasi peran Kodim 0613/Ciamis dalam menangani tanggap darurat bencana alam dan implikasinya terhadap ketahanan wilayah di Kabupaten Ciamis Jawa Barat?

Dalam penelitian ini digunakan beberapa teori yang sesuai dengan tema penelitian. Secara umum, pengertian optimalisasi adalah pencarian nilai "terbaik dari yang tersedia” dari beberapa fungsi yang diberikan pada suatu konteks. Dalam matematika dan ilmu komputer, optimasi atau optimalisasi mengacu pada pemilihan elemen terbaik dari beberapa set alternatif yang tersedia. Dalam kasus yang paling sederhana, ini berarti memecahkan masalah-masalah di mana orang berusaha untuk meminimalkan atau memaksimalkan fungsi dengan sistematis memilih nilai-nilai variabel integer atau real dari dalam set yang diperbolehkan (Fritz, 1999). Menurut Pareto (1896, dalam Winata, 2001) konsep mengenai optimalitas dalam bahasa yang lebih sederhana, alokasi sumber daya yang optimal dapat dicapai jika sudah tidak mungkin lagi membuat orang lebih baik tanpa membuat orang lain lebih buruk. Dengan demikian, optimalisasi kinerja adalah usaha pemanfaatan yang relatif singkat dengan biaya yang minimum untuk mencapai suatu pekerjaan dengan hasil dan keuntungan yang baik, sehingga kinerja tersebut mampu bersaing dengan yang lain.

Groos, Mason, dan McEachern (1958) mendefinisikan "peran sebagai seperangkat harapan-harapan yang dikenakan pada individu yang menempati kedudukan sosial tertentu (Berry, 2003 : 105)”. Menurut Talcot Parsons (1951), di dalam peranan terdapat dua macam harapan, yaitu (1). Harapan-harapan dari masyarakat terhadap pemegang peran atau kewajiban-kewajiban dari pemegang peran, dan (2). Harapan-harapan yang dimiliki oleh si pemegang peran terhadap "masyarakat" atau terhadap orang-orang yang berhubungan dengannya dalam menjalankan kewajibankewajiban atau perannya (Berry, 2003 : 107). Istilah peran diambil dari dunia teater, Sarwono mengatakan bahwa "dalam teater, seorang aktor harus bermain menjadi seorang tokoh tertentu dan posisinya sebagai tokoh itu, ia diharapkan berperilaku sebagai tokoh tertentu (Sarwono, 2006 : 215)”.

Pengertian bencana alam menurut Undang-Undang Nomor 24 Tahun 2007 adalah bencana yang diakibatkan oleh peristiwa atau serangkaian peristiwa yang disebabkan oleh alam, antara lain berupa gempa bumi, tsunami, gunung meletus, banjir, kekeringan, angin topan, dan tanah longsor. Bencana merupakan 
Ito Hediarto, Armaidy Armawi, Edhi Martono -- Optimalisasi Peran Kodim Dalam Penanganan Tanggap Darurat Bencana Alam Dan Implikasinya Terhadap Ketahanan Wilayah (Studi Di Kodim 0613/Ciamis, Jawa Barat)

pertemuan dari tiga unsur, yaitu ancaman bencana, kerentanan, dan kemampuan yang dipicu oleh suatu kejadian. Bencana bukan hanya bencana alam, bencana dapat terjadi karena faktor alam maupun non alam seperti budaya, agama, dan tentu saja manusia.

Ketahanan wilayah tidak dapat dipisahkan dengan ketahanan nasional. Menurut Basri (2006) bangsa Indonesia dapat menjaga keberlangsungannya dengan menggunakan konsep ketahanan nasional dalam mengatasi ancaman, tantangan, hambatan dan gangguan. Oleh sebab itu perlu dipelihara dan dikembangkan. Ketahanan nasional ditopang oleh ketahanan wilayah, dimana ketahanan wilayah harus ditopang oleh ketahanan masyarakat, serta ketahanan masyarakat harus diawali pula dengan ketahanan keluarga, sedangkan ketahanan keluarga itu harus didukung oleh terwujudnya ketahanan individu.

Penelitian ini merupakan penelitian deskriptif kualitatif. Menurut Sugiyono (2008) metode penelitian deskriptif merupakan metode penelitian untuk membuat gambaran mengenai situasi atau kejadian, sehingga metode ini berkehendak mengadakan akumulasi data dasar belaka.

Pemilihan jenis penelitian ini didasarkan atas pemikiran dan alasan bahwa permasalahan yang akan diteliti merupakan fenomena yang terjadi sebagaimana adanya berdasarkan faktafakta yang tampak di lapangan, hasil penelitian ini, akan mendeskripsikan fakta-fakta kondisi ketahanan wilayah setelah adanya peran Kodim 0613/Ciamis di Kabupaten Ciamis.

Teknik pengumpulan data yang digunakan adalah observasi, dokumentasi, dan wawancara mendalam untuk mendapatkan data kualitatif serta beberapa keterangan yang tidak diperoleh dari data sekunder. Tahap-tahap analisis data yang dilakukan meliputi reduksi data, display data, dan verifikasi data.

\section{PEMBAHASAN}

\section{Peran TNI Secara Umum}

TNI dalam melaksanakan tugas pokok pertahanan negara juga disiapkan untuk melaksanakan OMSP guna menghadapi berbagai bentuk ancaman di luar agresi militer. Penggunaan kekuatan TNI untuk OMSP dilaksanakan bersama sama dengan intansi fungsional dalam suatu keterpaduan usaha yang sinergis. OMSP dilaksanakan TNI dengan mendahulukan tindakan preventif daripada tindakan represif yang disesuaikan dengan eskalasi dan bentuk ancaman. OMSP diimplementasikan melalui peran/keikutsertaan TNI secara aktif dalam memecahkan permasalahan yang dihadapi bangsa di berbagai aspek kehidupan masyarakat, seperti peran dalam melindungi masyarakat dari ancaman bencana alam yang sering terjadi hampir di seluruh penjuru tanah air. Pengerahan kekuatan TNI untuk OMSP sesuai amanat UU Nomor 34/2004 Tentang TNI, dilaksanakan berdasarkan kebijakan atau keputusan politik negara. Terdapat 14 bidang tugas OMSP yang harus diemban TNI, yaitu (1). Mengatasi Gerakan Separatis Bersenjata. (2). Mengatasi Pemberontakan Bersenjata. (3). Mengatasi Aksi Terorisme. (4). Mengamankan Wilayah Perbatasan. (5). Mengamankan Obyek Vital Nasional yang bersifat strategis. (6). Melaksanakan tugas perdamaian dunia sesuai dengan kebijakan politik luar negeri. (7). Mengamankan Presiden dan Wakil Presiden beserta keluarganya. (8). Memberdayakan wilayah pertahanan dan kekuatan pendukungnya secara dini sesuai 
dengan sistem pertahanan semesta. Penggunaan kekuatan TNI dalam memberdayakan wilayah pertahanan dan kekuatan pendukungnya secara dini sesuai dengan sistem pertahanan semesta ditujukan untuk membantu pemerintah mempersiapkan ruang, alat dan kondisi juang secara dini di setiap wilayah NKRI sebagai suatu kesatuan pertahanan dengan memperhatikan hak masyarakat dan perundang-undangan melakukan koordinasi dengan kementerian terkait, serta pemerintah daerah dalam rangka pemberdayaan wilayah pertahanan guna kepentingan penyelenggaraan pertahanan negara dan bersama- sama institusi terkait lainnya menjaga stabilitas keamanan dan wilayah pertahanan di darat laut dan udara di seluruh wilayah NKRI. Kewenangan penggunaan kekuatan TNI untuk memberdayakan wilayah pertahanan dan kekuatan pendukungnya secara dini sesuai dengan sistem pertahanan semesta di bawah pengendalian panglima TNI. (9). Membantu Tugas Pemerintah Daerah. Penggunaan kekuatan TNI atas permintaan kepala Negara, ditujukan untuk membantu pelaksanaan fungsi pemerintah dalam kondisi dan situasi yang memerlukan sarana, alat dan kemampuan TNI untuk menyelesaikan permasalahan yang dihadapi. Bentuk bantuan dapat diberikan, yaitu membantu mengatasi akibat bencana alam, merehabilitasi infrastruktur, serta mengatasi masalah akibat pemogokan dan konflik komunal membantu melaksanakan ketertiban umum sesuai peraturan daerah dalam rangka mencegah gangguan penyelengaraan roda pemerintah daerah dan kelangsungan pembangunan daerah dan bersama-sama instansi terkait lainnya ikut aktif mengamankan dan merehabilitasi akibat ketidaklancaran kekuatan TNI untuk membantu tugas pemerintah di daerah pengendalian Panglima TNI. (10). Membantu Kepolisian Republik Indonesia dalam tugas keamanan dan ketertiban masyarakat. (11). Membantu mengamankan tamu negara setingkat Kepala Negara dan perwakilan pemerintah asing yang sedang berada di Indonesia. (12). Membantu menanggulangi akibat bencana alam, pengungsian dan pemberian bantuan kemanusiaan. Penggunaan kekuatan TNI untuk melakukan tindakan secara proporsional sesuai perundang-undangan yang berlaku; mencegah timbulnya korban dan atau kerugian yang lebih besar dalam pemberian bantuan; merencanakan area pengungsian, dan menyiapkan fasilitas dalam pemberian bantuan kemanusiaan; dan bersama-sama komponen bangsa lainnya memulihkan kondisi akibat bencana alam, penanganan pengungsian dan pemberian bantuan kemanusiaan. Kewenangan penggunaan kekuatan TNI untuk membantu menanggulangi akibat bencana alam, pengungsian, dan pemberian bantuan kemanusiaan berada dibawah pengendalian Panglima TNI. (13). Membantu pencarian dan pertolongan dalam kecelakaan (search and rescue). (14). Membantu pemerintah dalam pengamanan pelayaran dan penerbangan terhadap pembajakan, perompakan, dan penyelundupan.

Pada perwujudan Kekuatan Pokok Minimum (Minimum Essential Force/MEF) Tentara Nasional Indonesia (TNI) dengan tetap mengacu pada konsep pengembangan Postur Ideal TNI yang telah direncanakan dalam jangka panjang, pengertian Kekuatan Pokok Minimum (Minimum Essential Forcel MEF) adalah suatu standar kekuatan pokok dan minimum TNI yang mutlak disiapkan sebagai prasyarat utama serta mendasar bagi 
Ito Hediarto, Armaidy Armawi, Edhi Martono -- Optimalisasi Peran Kodim Dalam Penanganan Tanggap Darurat Bencana Alam Dan Implikasinya Terhadap Ketahanan Wilayah (Studi Di Kodim 0613/Ciamis, Jawa Barat)

terlaksananya secara efektif tugas pokok dan fungsi TNI dalam menghadapi ancaman aktual.

Prioritas pertama perwujudan MEF adalah peningkatan kemampuan mobilitas TNI Angkatan Udara (TNI AU), TNI Angkatan Laut (TNI AL) dan TNI Angkatan Darat (TNI AD) untuk mendukung penyelenggaraan tugas pokok TNI di seluruh wilayah nasional. Prioritas MEF selanjutnya adalah pada peningkatan kemampuan satuan tempur khususnya pasukan pemukul reaksi cepat, (striking force) baik satuan di tingkat pusat maupun satuan di wilayah, serta penyiapan pasukan siaga (standby force) terutama untuk penanganan bencana alam serta untuk tugastugas misi perdamaian dunia dan keadaan darurat lainnya. Kebutuhan-kebutuhan pendukung lain dalam rangka perwujudan MEF akan dipenuhi pula secara bertahap, sehingga diharapkan perwujudan MEF akan dipenuhi pula secara bertahap dan MEF dapat dijadikan sebagai pijakan dasar menuju postur TNI yang ideal.

Di samping itu, kebijakan kerja sama internasional bidang pertahanan pemerintah mengembangkan kerjasamayang bernilaipositif bagi kepentingan nasional dan lingkungan internasional, dengan memperhatikan prinsip saling menghormati, mempercayai, dan menguntungkan. Kerja sama internasional bidang pertahanan berkaitan dengan kebijakan politik luar negeri, sehingga harus senantiasa dilaksanakan dengan prinsip one gate policy. Segala bentuk kerjasama internasional bidang pertahanan menghindari bentuk pembentukan suatu fakta pertahanan yang dapat mengurangi makna politik luar negeri Indonesia yang bebas dan aktif. Salah satu prioritas kerja sama internasional bidang pertahanan di arahkan pada peningkatan kerja sama dengan Negara-negara sahabat yang memiliki komitmen tinggi terhadap pengembangan kemampuan (capacity building) pertahan Negara Indonesia, khususnya dalam upaya penanganan terorisme, kegiatan bidang pendidikan dan latihan, pengembangan sumber daya manusia, penanggulangan bencana, penegakan hukum di laut dan di udara, serta transfer teknologi untuk alat utama sistem senjata (alutsista) TNI.

\section{Keterlibatan TNI Dalam Penanggulangan Bencana}

Dalam berbagai bencana, sudah menjadi tugas dan kewajiban sebagai anggota TNI untuk membantu menangani bencana, sehingga penderitaan rakyat dapat dikurangi, bahkan dapat diselesaikan dengan baik. Pada mulanya anggota TNI melaksanakan tugas itu karena perintah. Namun melihat kesungguhan anggota TNI, kita berkeyakinan bahwa anggota TNI menjalankan tugas itu bukan hanya karena perintah, melainkan karena solidaritas sosial sesama anak bangsa. Sebagai bukti bahwa anggota TNI melaksanakan tugas itu karena solidaritas sosial, bukan hanya karena perintah, adalah mereka selalu memberikan sumbangsih yang besar di daerah bencana, melebihi tugas formal mereka, karena itu wajar jika di daerah bencana kedatangan anggota TNI selalu disambut dengan hangat dan penuh harapan. Apalagi anak bangsa yang paling siap untuk menghadapi bencana alam dan semacamnya adalah anggota TNI.

Perlu diakui bahwa dalam situasi bencana yang mengakibatkan kerusakan berbagai infra struktur vital, serta jatuhnya korban dalam jumlah besar, seperti yang terjadi di Pangandaran tahun 2006, dan Banjir bandang 
di Kecamatan Cihaurbeuti Ciamis pada tahun 2011, TNI pada umumnya serta Kodim 0613/Ciamis dan jajaran pada khususnya, merupakan institusi paling solid dan jadi garda terdepan untuk melakukan pertolongan pertama (immediate response) terutama dalam penyelamatan korban. Karena itu, merupakan hal yang paling penting untuk mencantumkan tugas spesifik ini sebagai bagian dari upaya tanggap darurat pada tingkat yang paling ekstrim dan memerlukan penanganan secara cepat. Untuk itu, tentunya diperlukan suatu Standart Operation Procedures (SOP) yang jelas bagaimana TNI harus bertindak dalam situasi immediate response, sehingga tindakan yang dilakukan efektif dan sesuai dengan kebutuhan lapangan. Dalam konteks immediate response, TNI harus bertindak cepat, karena tuntutan situasi dan kodisi, akan tetapi amanat UU 24/2007 dan regulasi turunan tidak secara eksplisit mengatur keterlibatan TNI pada tataran implementatif. Inilah yang menjadi kendala di lapangan, pada saat terjadi bencana di wilayah Ciamis, TNI (Kodim 0613/Ciamis) selalu berinisiatif cepat dalam penanganannya namun justru instansi yang terkait langsung seperti Pemda dan BPBD belumlah bergerak.

Dalam hal menghadapi bahaya atau ancaman bencana, TNI masih dianggap sebagai salah satu organisasi atau komponen bangsa yang memiliki kemampuan untuk melindungi dan menyelamatkan warga Negara dari ancaman musuh yang bernama bencana alam, baik gempa bumi maupun tsunami. Akan tetapi ironinya adalah sesuai tugas pokok TNI di bidang OMSP menurut UndangUndang Nomor 34 tahun 2004 tentang TNI secara jelas mengamanatkan kepada TNI untuk membantu menanggulangi akibat bencana alam, pengungsian dan pemberian bantuan kemanusiaan, akan tetapi didalam ketentuan undang-undang Nomor 24 Tahun 2007 Tentang Penanggulangan Bencana, keterlibatan TNI tidak secara jelas dan tegas sebagai unsur pelaksana atau aktor penting dalam implementasi upaya penanggulangan bencana di wilayah, akan tetapi hanya sebagai salah satu unsur pengarah dari 10 Pejabat Pemerintah Eselon I Kementerian Negara yang dilibatkan, sehingga kondisi ini sangat dilema bagi pelaksanaan tugas TNI khususnya Komando Wilayah seperti Kodim 0613/ Ciamis yang kedudukannya berada di daerah rawan bencana. Di samping itu juga, di tengah keterbatasan dana, sarana dan prasarana yang dimiliki Kodim/0613 Ciamis juga dituntut agar mampu merespon secara cepat, tepat dan terukur dalam upaya penanggulangan bencana yang terjadi di wilayahnya.

\section{Peran Kodim 0613/Ciamis Dalam Menangani Tanggap Darurat}

Meskipun pemerintah telah membentuk BPBD daerah kabupaten Ciamis berdasarkan pada UU Nomor 24 tahun 2007 Tentang Penanggulangan Bencana, namun karena adanya berbagai kendala badan ini masih mengalami keterbatasan dalam menanggulangi bencana seperti bencana banjir bandang di Kecamatan Cihaurbeuti Kabupaten Ciamis, khususnya pada saat tanggap darurat, yang tentunya diperlukan tindakan yang cepat dengan personel yang terlatih dan organisasi yang solid, dimana dengan kondisi dengan suasana yang hampir terdadak, serba terbatas dan minimnya pengalaman di tuntut untuk mampu merespon bencana alam tersebut.

Oleh karena itu peran serta dan keterlibatan TNI Khususnya TNI AD, terutama 
Ito Hediarto, Armaidy Armawi, Edhi Martono -- Optimalisasi Peran Kodim Dalam Penanganan Tanggap Darurat Bencana Alam Dan Implikasinya Terhadap Ketahanan Wilayah (Studi Di Kodim 0613/Ciamis, Jawa Barat)

Kodim 0613/Ciamis sangat penting sekali terutama dalam membantu mengurangi dampak bencana seperti banjir bandang yang terjadi di wilayah Cihaurbeuti kabupaten Ciamis pada tanggal 28 Maret 2011, yang mengakibatkan dua orang meninggal dunia dan sekitar tujuh ratus orang masyarakat mengungsi dari lokasi bencana.

Menurut Keterangan Dandim 0613/ Ciamis pada waktu itu tanpa mengurangi peran arti dari BPBD dan pemerintahan daerah Ciamis, Kodim 0613/Ciamis dan jajarannya bergerak cepat membantu para korban bencana alam banjir bandang yang tentunya sudah dilaksanakan koordinasi dengan instansi terkait.

Dalam membantu mengatasi banjir bandang dan bencana alam lainnya Kodim 0613/Ciamis berpegang teguh pada aturan hukum yang tertuang pada UU Nomor 24 tahun 2007 tentang penanggulangan bencana, khususnya pada pasal 48, di mana penanggulangan bencana pada saat tanggap darurat meliputi (1). Pengkajian secara cepat dan tepat terhadapi lokasi kerusakan dan sumber daya, (2). Penentuan status keadaan darurat bencana, (3). Penyelamatan dan evakuasi masyarakat terkena bencana, (4). Pemenuhan kebutuhan dasar,(5). Perlindungan terhadap kelompok rentan, dan (6). Pemulihan dengan segala prasarana dan sarana vital.

\section{Kendala yang dihadapi Kodim 0613/ Ciamis}

Adapun kendala utama yang dihadapi pada saat koordinasi dengan Pemerintahan Daerah adalah sebagai berikut.

Pertama, jarak yang jauh. Hal ini merupakan suatu kendala dalam pelaksanaan koordinasi. Demikian juga pada saat dilaksanakannya tanggap darurat, seperti pada masa tsunami di Pangandaran dan Banjir Bandang di Cihaurbeuti Ciamis. Pada saat itu ternyata sulit sekali dalam melaksanakan koordinasi mengingat jarak dari Pangandaran ke Ciamis sekitar $100 \mathrm{Km}$.

Kedua, waktu. Dengan tingkat kesibukan yang tinggi masalah waktu dapat menjadi suatu kendala pada saat dilaksanakannya koordinasi. Sedangkan saat koordinasi dengan SKPD Kabupaten Ciamis adalah sulitnya mendapatkan jawaban yang pasti ketika berkoordinasi untuk hal yang penting karena Kepala Dinas bukan pengambil kebijakan yang strategis.

Ketiga, anggaran. Masalah anggaran semuanya bermuara pada Bupati Ciamis. Artinya ketika berbicara tentang anggaran ternyata pemegang kebijakannya adalah bupati, sedangkan untuk kepala BPBD hanya sebagai pemegang kekuasaan teknis, berkaitan dengan pelaksanaan evakuasi masalah tanggap darurat. Kepala BPBD bukan sebagai pemegang kebijakan strategis dalam penentuan anggaran, semua bermuara pada Bupati Ciamis.

Keempat,minimnya sarana dan prasarana. Sarana dan prasarana yang ada pada saat penanganan pertama korban tsunami ternyata berdampak pada lambatnya proses evakuasi dan penyelamatan korban. Banyak korban yang tidak tertolong karena tertindih bangunan. Sarana kesehatan merupakan hal yang utama pada saat terjadi bencana alam. Banyak korban yang akhirnya tidak tertolong karena diakibatkan tim kesehatan yang minim, sedangkan sebaran daerah terdampak bencana sangat luas. Personel kesehatan yang ada di daerah mesti bekerja keras menghadapi situasi bencana dan dengan sarana serta prasarana 
yang dimiliki, sehingga kadangkala perlu menunggu datangnya bantuan dari kesehatan pusat.

\section{Strategi optimalisasi peran yang dilaksanakan}

Keterlibatan TNI dalam perbantuan bencana alam tersurat dalam Undang-undang Nomor 24 tahun 2007 tentang Penanggulangan Bencana dan Undang-undang Nomor 34 tahun 2004 tentang TNI. Dalam Undang-undang Nomor 24 tahun 2007 menyatakan bahwa TNI sebagai pengarah, sedangkan dalam peraturan No 1 Kepala BNPB tahun 2008, menyebutkan bahwa Bupati/Walikota dapat menunjuk salah satu eselon tertinggi sebagai Komandan posko tanggap darurat, dan biasanya menunjuk Sekda Kabupaten. Dengan demikian berkaca dari kasus di wilayah Kabupaten Ciamis maka perlu dilaksanakan evaluasi tentang pelibatan TNI dalam bencana seperti yang disampaikan diatas. Untuk itu dapat dilakukan perubahan bahwa TNI sebagai Komandan posko tanggap darurat/incident commander (IC). Dengan demikian untuk Kabupaten Ciamis nampaknya perlu dikaji kembali dan dapat dijadikan model untuk daerah lain bila memiliki kondisi alam yang relatif sama dimana hampir sepanjang tahun selalu terjadi bencana.

Ke depan bila terjadi bencana alam dengan skala besar dan perlu dikeluarkan kondisi tanggap darurat, maka berdasarkan pengalaman yang sudah diterapkan di wilayah Ciamis seyogyanya Dandim 0613/Ciamis diberikan peran yang lebih besar dalam mengambil tindakan saat tanggap darurat. Bupati dapat menunjuk Komandan Kodim (Dandim) sebagai komandan posko tanggap darurat, sehingga Dandim dapat mengambil tindakan cepat dalam menolong dan mengevakuasi korban serta mengembalikan kondisi lingkungan yang rusak akibat bencana kembali normal. Tugas sebagai pengarah yang hanya mengarahkan saja terhadap kegiatan tanggap darurat nampaknya tidaklah tepat disandang oleh Dandim 0613/Ciamis, mengingat Kodim 0613/Ciamis banyak berbuat dalam kegiatan tanggap darurat di Kabupaten Ciamis. Memang langkah tersebut diambil tidaklah sesuai dengan ketentuan perundang-undangan saat ini, akan tetapi berdasarkan pengalaman yang ada maka korban bencana alam dapat dengan segera ditolong dan lingkungan kembali normal berkat peran Kodim 0613/Ciamis yang cukup luas dalam tanggap darurat saat itu. Dengan demikian tugas Kodim 0613/Ciamis dapat lebih optimal dalam melaksanakan perbantuan terhadap pemerintah daerah untuk pengentasan tugas tanggap darurat bencana alam.

Perumusan ulang mekanisme penanggulangan bencana alam tahap tanggap darurat yang berlaku di Kabupaten perlu segera dilaksanakan seperti yang terjadi di Kabupaten Ciamis. Hal ini didasari oleh kondisi di wilayah Ciamis yang sering terkena bencana, dan Kodim 0613/Ciamis merupakan instansi yang paling siap dalam membantu bencana alam karena gelar kekuatan hampir di setiap kecamatan, dan memiliki personel di setiap daerah. Selain itu dengan pengalaman yang cukup dalam penanggulangan bencana. Peran Kodim 0613/Ciamis yang sangat signifikan dalam membantu dan mengevakuasi korban dapat dijadikan pijakan untuk merubah mekanisme penanggulangan bencana alam khususnya tahap tanggap darurat yang berlaku di Kabupaten Ciamis.

Dengan kondisi Dandim 0613/Ciamis yang semula menjadi pengarah pada kondisi 
Ito Hediarto, Armaidy Armawi, Edhi Martono -- Optimalisasi Peran Kodim Dalam Penanganan Tanggap Darurat Bencana Alam Dan Implikasinya Terhadap Ketahanan Wilayah (Studi Di Kodim 0613/Ciamis, Jawa Barat)

tanggap darurat, sedangkan Sekda Ciamis yang ditunjuk Bupati Ciamis sebagai Komandan Posko tanggap darurat, maka dapat dirumuskan kembali dengan analisis pengalaman, kecepatan dan gelar pasukan Kodim di seluruh wilayah Ciamis sehingga dapat dibuat perubahan. Dandim 0613/Ciamis dapat dijadikan sebagai Komandan Posko Tanggap Darurat di wilayah Ciamis, sementara instansi lain tetap sebagai pengarah sesuai dengan aturan yang berlaku.

Dengan ditunjuknya Dandim0613/Ciamis sebagai Komandan Posko Tanggap Darurat, maka dapat dengan segera menggerakan anggotanya guna membantu dan menolong serta mengevakuasi korban, selain itu Dandim 0613/Ciamis dapat segera memperbaiki kondisi lingkungan yang terdampak bencana alam. Kondisi ini terjadi di wilayah Ciamis dengan berbagai kekhususan yang terjadi. Tetapi tidak salah juga dengan beberapa pendapat yang disampaikan diatas maka daerah lain dapat menjadikan Dandim sebagai Komandan Posko Tanggap Darurat.

\section{Implikasinya Terhadap Ketahanan Wilayah}

Konsep Ketahanan Wilayah merupakan bagian integral dari konsep Ketahanan Nasional. Dalam persepektif Ketahanan Nasional, kondisi di tingkat nasional merupakan merupakan himpunan kualitas dari ketahanan individu yang secara berjenjang membentuk ketahanan keluarga, ketahanan kelompok, ketahanan wilayah atau daerah, ketahanan nasional dan ketahanan regional. Masingmasing komponen secara sinergis membentuk penangkalan berlapis berupa lingkaranlingkaran ketahanan konsentris yang berpusat pada pribadi tiap-tiap individu masyarakat.
Dalam arsitektur plastis tersebut, maka lingkaran penangkalan yang terdalam akan berupa ketahanan pribadi dari setiap individu dalam menghadapi ancaman, tantangan, hambatan dan gangguan dari lingkungannya.

Penanggulangan secara langsung khususnya tahap tanggap darurat bencana alam oleh Kodim 0613/Ciamis akan berdampak pada gatra ideologi, politik, ekonomi dan sosial budaya, serta pertahanan dan kemanan.

Pertama, gatra ideologi. Penanganan bencana oleh pemerintah dan Kodim 0613/ Ciamis membuat masyarakat semakin percaya terhadap pemerintah, dengan demikian akan menciptakan kondisi dimana mereka tidak akan terpengaruh oleh paham-paham lain yang bertentangan dengan pemerintah, karena mereka merasa sangat diperhatikan oleh pemerintah Kabupaten Ciamis.

Kedua, gatra politik. Ketika pemerintah tidak dapat mengatasi dampak bencana alam, maka warga dengan berbondongbondong mendatangi pemerintah daerah guna menanyakan mengapa pemerintah tidak ikut dalam menangani bencana. Akhirnya yang terjadi adalah adanya tambahan permasalahan bagi pemerintah daerah karena aksi unjuk rasa yang ada. Untuk itu sudah benar bila pemerintah daerah dan aparat lainnya serta masyarakat ikut serta dalam menanggulangi bencana. Dengan demikian aksi protes yang dapat mengganggu situasi politik di daerah bisa dieliminir.

Ketiga, gatra ekonomi. Dengan adanya perbaikan kondisi lingkungan dan segala fasilitas milik publik di daerah terkena bencana maka akan mengembalikan segala kegiatan masyarakat, termasuk geliat kegiatan perekonomian. Masyarakat sudah mau melaksanakan aktivitas sehari-hari termasuk 
melaksanakan kegiatan jual-beli di pasar atau pertokoan. Mereka dapat tertolong dengan diperbaikinya lingkungan mereka yang terkena bencana. Untuk itu dengan adanya peran dari Kodim 0613/Ciamis dan pemerintah daerah dalam tanggap darurat bencana alam dan perbaikan lingkungan bencana, maka akan mengembalikan kehidupan masyarakat seperti sediakala, sehingga kehidupan perekonomian di daerah dapat berjalan kembali.

Keempat, gatra sosial budaya. Dengan ditingkatkannya peran Kodim 0613/Ciamis dalam penanggulangan bencana di Ciamis, maka akan mengembalikan pranata sosial yang terserak. Sistem sosial yang sudah dibangun di daerah tersebut akan kembali terjalin. Hubungan/interaksi antar warga akan kembali terjadi. Dengan demikian geliat warga yang semula tidak terlihat dapat dikembalikannya situasi seperti dahulu lagi, sehingga akan terdampak pada harmonisasi masyarakat dan kembalinya kehidupan masyarakat yang terdampak bencana alam seperti sediakala. Pelaksanaan rehabilitasi pasca bencana alam oleh Kodim 0613/Ciamis, berdampak secara langsung pada aspek sosial budaya.

Kelima, gatra pertahanan keamanan. Situasi pada saat bencana merupakan situasi yang mencekam, masyarakat terlihat ketakutan dan trauma akibat bencana. Akan tetapi setelah dilaksanakannya tanggap darurat di wilayah Ciamis pasca tsunami Pangandaran dan banjir bandang di Cihaurbeuti, maka sedikit demi sedikit mengembalikan situasi daerah yang tadinya kurang bersahabat menjadi daerah yang seperti dahulu lagi. Pada saat terjadi bencana banyak warga luar daerah yang melakukan kejahatan di lokasi bencana, sedikit demi sedikit hilang karena dengan turunnya warga dan aparat untuk menjaga lingkungannya yang ditinggalkan, apalagi setelah kondisi kembali normal dan masyarakat kembali ke tempat tinggalnya, maka daerah tersebut sudah kembali seperti dahulu lagi.

\section{SIMPULAN}

Berdasar penjelasan tersebut di atas dapat ditarik simpulan sebagai berikut.

Pertama, peran Kodim dalam ikut serta membantu masyarakat dalam bencana alam sangatlah signifikan, dimana pada beberapa kejadian bencana alam seperti tsunami di Pangandaran tahun 2006 dan banjir bandang di Kecamatan Cihaurbeuti Ciamis tahun 2011, Kodim 0613/Ciamis langsung ikut membantu dalam evakuasi dan menolong secara langsung korban bencana alam. Banyak masyarakat yang menjadi korban tsunami ditemukan oleh anggota Kodim 0613/Ciamis pada saat melakukan evakuasi korban. Demikian juga pada saat dilaksanakannya tanggap darurat oleh pemerintah daerah, Kodim 0613/Ciamis membantu secara langsung baik pada saat pengkajian secara cepat dan tepat terhadap lokasi kerusakan dan sumber daya, penentuan status keadaan darurat bencana, penyelamatan dan evakuasi masyarakat terkena bencana, pemenuhan kebutuhan dasar, perlindungan terhadap kelompok rentan dan pemulihan dengan segala prasarana dan sarana vital. Langkah ini dilakukan semata-mata karena keikutsertaan TNI dalam penanggulangan bencana tersurat dalam UU No 34 Tahun 2007 tentang TNI dan UU No 24 tahun 2007 tentang Penanggulangan Bencana.

Kedua, keterlibatan Kodim 0613/Ciamis secara langsung dalam penanggulangan bencana nampaknya perlu dilakukan pengkajian ulang terhadap mekanisme perbantuan TNI pada pemerintah daerah pada 
Ito Hediarto, Armaidy Armawi, Edhi Martono -- Optimalisasi Peran Kodim Dalam Penanganan Tanggap Darurat Bencana Alam Dan Implikasinya Terhadap Ketahanan Wilayah (Studi Di Kodim 0613/Ciamis, Jawa Barat)

saat terjadi bencana. Khusus untuk wilayah Ciamis dimana keterlibatan Kodim 0613/ Ciamis sangat luar biasa pada saat awal terjadi bencana, prajurit dengan bekerja keras betulbetul ingin menyelamatkan warga yang hilang atau tertimpa bangunan. Kodim 0613/Ciamis dengan segala kemampuannya melaksanakan kegiatan pemulihan daerah bencana. Kondisi tersebut dilakukan langsung dibawah kepemimpinan Dandim 0613/Ciamis. Untuk itu tidaklah salah bila Bupati dapat menunjuk langsung Dandim sebagai Komandan Posko tanggap darurat bencana, sehingga dengan pengalaman dan kebersamaan prajuritnya dapat melakukan langkah dan tindakan yang cepat guna pemulihan pasca bencana.

Ketiga, pelaksanaan tanggap darurat yang dilakukan oleh Bupati Ciamis terhadap bencana tsunami dan banjir bandang dapat berdampak kembalinya kepercayaan masyarakat pada ideologi Pancasila, menguatkan situasi politik, mengembalikan kondisi ekonomi yang hilang, dan mengembalikan kehidupan sosial masyarakat, serta situasi keamanan di wilayah terdampak bencana. Dengan demikian tanggap darurat guna mengembalikan situasi kondisi pasca bencana berimplikasi pada ketahanan wilayah di Kabupaten Ciamis yang meliputi gatra ideologi, politik, ekonomi, sosial budaya, pertahanan dan keamanan.

\section{DAFTAR PUSTAKA}

Berry, David, 2003, Pokok-Pokok Pikiran Dalam Sosiologi, Jakarta, PT Raja Grafindo Persada.

Basrie, Chaidir, 2006, Teori Ketahanan Nasional : Gagasan, Proses, Kajian dan Pengembangan, Yogyakarta, Sekolah Pasca Sarjana UGM.
Fritz, Horas Silalahi, 1999, Hukum Investasi Sebagai Penggerak Penciptaan Lapangan Kerja, Jakarta, BKPM.

Giri Ahmad Tufik, 2006, Bencana Alam dan Pengungsi, Jakarta : Komnas HAM.

Kuntjoro dan Sofiah Jamil, 2010 : Eastasiaforum.

Mabesad, 1991, Ketahanan Pribadi dan Ketahanan Keluarga Sebagai Tumpuan Ketahanan Nasional, Jakarta : Setumad.

Nazir, Moh, 2005, Metode Penelitian, Bogor : Ghalia Indonesia.

Ratih Tri Hanawati, 2011, Implementasi Kesiapsiagaan Bencana Berbasis Masyarakat (KBBM) dalam Mitigasi Bencana di Kabupaten Malang.

Richard Conan-Davies, 2003, Disaster Resilience.

Ruswandi, 2008, Identifikasi Potensi Bencana Alam dan Upaya Mitigasi yang Paling Sesuai Diterapkan di Pesisir Indramayu dan Ciamis.

Sarlito, 2006, Teori-Teori Psykologi Sosial, Jakarta : PT Raja Grafindo Persada.

Sarwono, Jonathan, 2006, Metode Penelitian Kuantitatif dan Kualitatif, Yogyakarta, Graha Ilmu.

Sugiyono, 2008, Metode Penelitian Kuantitatif, Kualitatif Research and Development, Bandung , Alfabeta.

Winata, 2001, Optimalisasi Pengelolaan dan Pemanfaatan SDM serta SDA.

\section{Peraturan Perundangan}

Undang-Undang RI Nomor 34 tahun 2004 Tentang TNI.

Undang-Undang RI Nomor 24 tahun 2007 Tentang Penanggulangan Bencana 